\title{
Zhivaia Starina in 2016
}

\author{
Maria V. Akhmetova \\ The Russian Presidential Academy of National Economy and \\ Public Administration \\ Moscow, Russia
}

In 2016 Zhivaia Starina published the results of regional folklore studies, the activities of Russian academic folklore and ethnographic centers, fieldwork and materials and archives. Much attention was given to a variety of vernacular literary documents (from Old Russian manuscripts to naive literature and peasant memoirs).

The first issue opened with a new section "In the academician's study." The section features interviews with leading Russian and international specialists in folklore and traditional culture. The first offering was an interview with S. Yu. Neklyudov (the journal's former editor-in-chief, current member of the editorial board) "From King Gesar to the Persian Princess." The author tells the reader about his academic path to folklore studies and shares his professional plans for the future.

The section "Folklore and ethnography of the Russia's peoples" brought together articles on family rites, demonology, and folktales of the Romani (N. V. Bessonov, "Fetters on the girls from Gypsy's camps"); the Kabardians (A. V. Koz'min, "Materials on ethnography and mythology of the Adighe aul Oulyap"); the Altaiac peoples (D. Yu. Doronin, "Between a goat and a cannibal: Mythological narratives about the Almyses in Altai"); the Nağaybäks (S. Yu. Beloroussova, “'Here Nağaybäk's soul opens': Commemorational rite Ash Biru"); and the Mordvins (V. I. Rogachev, "Funeral rites of the Erzya and Moksha").

The section "Regional folklore: The Ukrainian enclave in the Saratov region" was dedicated to the materials from ethnolinguistic expedition to the Samoylovsky district (Saratov region, Middle Volga) by the Centre for Typological and Semiotic Folklore Studies in the Russian State University for the Humanities). The study of this Ukrainian enclave in the Saratov region addresses the rite of 
announcing bride's virginity (N. N. Rychkova), the image of magicians (M. I. Baiduzh), beliefs in communication with the dead (D. I. Antonov), and rituals of buying and selling of cattle (S. S. Makarov). The preface to the section was written by E. E. Levkievskaya, head of the expedition.

The section "Mythological personages in folklore" reviews both traditional and contemporary folk material. E. A. Dorokhova's article presented narratives about so-called dobrokhoty [invisible/hidden people] recorded in 1989 and 2014 on the border between Russia and Belarus' (the Novozybkovsky District in Bryansk region and the Vetka district in the Gomel region). M. O. Garder analyzed the motif 'cows appear from the water,' which is widespread in the Russian North and seems to be analogous to Finnish folktales. V. I. Shilkin discussed material on magicians and witches collected in Volgograd region. O. V. Boitsova reveals the genesis of image of the imaginary donor ('hares' and 'foxes') that parents invented to give presents to their children and transformation of this image in the $20^{\text {th }}$ century.

The section "Expeditions" includes the material collected in the Velsky district, Arkhangelsk region (articles by E. P. Strel'tsova, A. Yu. Ulanova, O. Yu. Emets and A. P. Strel'tsova); in the Dyachkino Sloboda in Rostov region (A. V. Bredikhin); and in the village of Volokovaya in Nenets Autonomous Okrug (A. N. Rassykhaev).

The second issue opened with the section "Word-textimage" dedicated to the visual aspects of the traditional culture. L. $\mathrm{N}$. Vinogradova analyzes the image of death personified in the iconography of Western Europe and Old Russia and compares it with Slavic beliefs. V. Ya. Petrukhin reviews 'obscene' motifs in descriptions of mythological personages and creatures mentioned in chronicles, comparing them with personages from Russian and Finno-Ugrian folklore. The article "Burial altars: Literary solutions to archaeological problems" by L. A. Belyaev provides ethnoarchaeological commentary to literary references to burials on altars that contradict the tradition (but not the canon). G. I. Kabakova discovered the literary source of a $19^{\text {th }}$ century lubok 'Genesis and evolution of Baba Yaga' - 'The Tale of the Nobleman of Zaoleshye...' by V. Levshin (1780)." The article "About bliny, the 
son-in-law and the mother-in-law" by A. B. Moroz is based on the lubok 'Bliny-maker' (the end of the $18^{\text {th }}$ century) and discusses erotic connotations connected with pancakes and the process of making them in calendar rituals, wedding rites, and non-ritual folklore. O. Yu. Boitsova analyzes the vernacular prohibition on taking photos from a semiotic viewpoint.

Regional material from Perm made up the section "Folklore studies in academic centers: The Perm University." E. M. Chetina gave an overview of the activities of the Laboratory of Visual and Cultural Anthropology at Perm State University. The articles included in the section present the results of collecting and academic conceptualization of peasant's written memoirs and family chronicles: "'Everything happened, both good and bad...' ('Story of One Family' by Nina Ivanova)" by E. M. Chetina and E. A. Klyuikova; "Modern rural biographic narrative: Galina Anfyorova's essay 'Granny"' by S. Yu. Korolyova, K. V. Vinogradova, and N. M. Teplova; materials on naïve literature "'Home poetry' by Pyotr Ivanov" by A. S. Belomestnova, and I. V. Osipova; "'Life story and fate in form of poems' (works by Ekaterina Zvereva)" by M. V. Kurochkina and S. Yu. Korolyova; " Naïve' civic poetry by Georgy Bashkirtsev: texts and contexts" by B. V. Kondakov and M.V. Kurochkina.

The section "Regional folkore: Eastern frontier of the Vologda and Kostroma regions" presents the material collected during the Toponymical expedition by the Ural Federal University in 2015 (in the south of the Sharyinsky district in Kostroma region, the western and central parts of the Nikolsky district in Vologda Region, the south of the Kichmengsko-Gorodetsky district in Vologda Region, and the Pyshchugsky district in Vologda Region). E. L. Berezovitch, V. S. Kuchko and O. D. Surikova publish and comment on magic spells and laments. K. A. Bormotova and Ya. V. Mal'kova analyze phraseological units and idioms expressing the beliefs about the supernatural: "to raise Jesus Christ" (the tradition to cook kisel at the Ascension of Jesus); "the dead man bite/pinch" (about a bruise), "a magician stayed overnight" (about a badly heated banya), etc. E. L. Berezovitch and T. V. Leontyeva review a particular form of chastushkas as navetka [hints] from the viewpoint of their content 
(information on the love life of the singer) and discuss etymology of name of these chastushkas. V. S. Kuchko addresses the dialect lexis regarding the concept of deceit.

The "Expeditions" section includes the material collected in Belarus' ("Narratives about obmiraniia [death experiences] in the Krychaw district of the Mogilyov region" by O. V. Belova). The "Jubilees" section marks the ninetieth birthday of V. G. Smolitskiy, theorist of literature and folklorist and author of numerous works on epic folklore, history of folklore studies, folklore in Russian literature, etc. (article by O. V. Belova).

The third issue opened with the section "Folklore and literacy" and presented a range of materials, including the $18^{\text {th }}$ century compilation of tips and tricks and magical prescriptions (A. L. Livshits); a folk prayer for cattle with the mention of mysterious creatures chiuchelo and miachelo from $18^{\text {th }}$ century manuscripts (A. V. Dadykin and V. I. Erofeeva); herbalist manuals from the $19^{\text {th }} / 20^{\text {th }}$ centuries (A. B. Ippolitova); manuscripts about magical stones: 'eagle stone', 'swallow stone', 'hen stone', etc., from the $18^{\text {th }}$ century Natural Book (O. V. Belova); and a manuscript of magic spells and folk prayers from Volgograd Region (V. A. Shilkin). A detailed folkloristic and linguistic commentary to the publication by A. V. Dadykin and V. I. Erofeeva was published in the fourth issue of the journal in the section "Reviews" ("Back to the Published: "chiuchelo-miachelo"” by E. L. Berezovitch, O. V. Belova).

The section "Ethno-confessional communication and folklore" featured articles dedicated to cooperation and mutual influence of representatives of different cultures and confessions. O. N. Palikova analyzes unofficial anthroponyms of mixed Russian and Estonian villages in the territories of the Western Chude, where the Russianspeaking population is represented by both Old and New Believers. S. N. Amosova studies folktales about the relations among the Latvians, Russian and Jews in the period between the two World Wars. M. G. Solomatina reviewed the expressions on faith and faithlessness in the Arkhangelsk dialects, providing broad linguistic material, with a focus on the lexis defining religious people and atheists.

A considerable portion of the articles published in the section 
"Folk costume" concerned the contemporary state of the culture of Russian Old Believers living in other ethnic environments. T. Morris (Yumsunova) dedicates her article to the clothes of the Old Believers living in the state of Oregon (USA); O. G. Rovnova wrote about the Old Believers in Latin America; and I. V. Dynnikova compared the Old Believers' clothes for the newborns and the dead in Latin America. Material on the Russian Old Believers was reviewed in the article by L.V. Sinitsyna titled "Traditional costumes of the Smolensk region".

The $30^{\text {th }}$ anniversary of the nuclear accident at the Chernobyl nuclear power plant was marked by the section "Chernobyl: After 30 years." This section included materials on the folk calendar, magic and demonology, and rites and religious folklore collected from the natives of the villages Sivenka and Chervonny Kut in the Vetka district of Gomel region who were resettled after the accident (G. I. Lopatin).

The year of 2016 marked the 20-year anniversary of the death of N. I. Tolstoy, academician and first editor-in-chief of Zhivaia Starina. The section "Memorable dates" contains two letters written in 1975 and 1994 by N. I. Tolstoy to the Byelorussian Slavist G. A. Tsykhun, his friend and colleague. The "Expeditions" section presented field materials collected in the Bryansk region ("The Week after Pentecost in the local tradition of the northeastern Bryansk region" by A. A. Mazhukina) and in the Oryol region ("Expedition to the Soskovsky district in the Oryol region" by P.A. Skrylnikov). The "Jubilees" section marked the birthday of SaintPetersburg folklore specialist and theorist of literature A. F. Belousov, a researcher of urban folklore and the culture and daily life of the pre-revolutionary and contemporary school, and local texts of Russian provinces (the article by M. V. Stroganov).

The first section of the fourth issue is dedicated to "Folk writing," including written vernacular memoirs, epistolaries and diaries. A. V. Pigin published excerpts from the diary of the peasant G. Ya. Sitnikov from the Mezensky district $\left(19^{\text {th }}-20^{\text {th }}\right.$ centuries $)$ concerning the cult of the local saint Iov Ushchel'skiy and his miracles. S. Yu. Korolyova and A. S. Belomestnova reviewed correspondence of the stranniki [wanderers] Old Believers' sect. 
Naïve memoirs were analyzed by S. Yu. Korolyova and K. V. Vinogradova ("'Just life' of the Komi-Permyak Klavdia Berenyuk"), by M. V. Stroganov (“"The memories I wrote down': Memoirs of M. M. Shirkina (Tver)"), and by N. M. Kurennaia ("From the 'Memoirs' by the Saint-Petersburg worker Boris Shteinfas").

A new section titled "Tradition - symbol - brand" was featured. The section is dedicated to local symbolism and engagement with traditional culture elements in local branding efforts. The article by E. V. Minyonok titled "“All-Sagutyevo's' feast 'Dremá" reviewed the process of the holiday restoration and outlined the differences between present and former celebrations. E. G. Boronina discussed the restoration of the traditional dance Quadrille in the Old Believers' village of Stepanovo (OrekhovoZuyevsky district in Moscow region). T. V. Volodina analyzed the semantics and erotic subtext of the Byelorussian ritual game "the Cat" ("to bake the cat", "to celebrate the cat", etc.) on the final day before the Nativity Fast. M. V. Akhmetova reviewed vernacular interpretations of the coat of arms of the city of Narva (Estonia). Material collected in Italy provided the basis for the article by S. A. Sidneva in which she described the patronal festival of Madonna, the saint patron of the Trastevere district of Rome. T. Gunnell highlighted the genesis and modern functioning of the characters of Fjallkonan (The Lady of the Mountain) in the Icelandic national tradition.

The section "Archival Files" included an article by T. K. Pasternak in which she examines the ethnographic activity of E. N. Kletnova (1869-1938) as well as the reflection of Russian folk motifs in her literary works. The publication by T. K. Pasternak entitled Legends of Local Peasants (with commentaries by M. V. Akhmetova and O. V. Belova) presented folk legends, fables and fairy-tales collected by E. N. Kletnova in 1910s.

"In the academician's study" centered on the career of the Slavist L. N. Vinogradova, member of the editorial board of Zhivaia Starina, who discussed her academic path and published excerpts from her 1970s field diaries. "Expeditions" presented materials collected in Ukrainian villages in Belgorod region (V. E. 
Dobrovol'skaya, "Traditional bakery in the Ukrainian village of Kozinka (Grayvoronsky district, Belgorod region)" and in villages of Old Believers in Latvia (A. A. Plotnikova, "About the expedition to the Latgalian Old Believers"). It also included expeditions by the center of Jewish Studies "Sepher" to the Vitebsk region in Belarus' (O. V. Belova), the Latgale region (Latvia), the Smolensk region (Russia) and to Israel (S.N. Amosova).

In 2016 the journal published 15 reviews of new scholarly publications, ( 8 on Russian publications and 7 on works from other countries), 8 academic chronicles, one conference review and a description of the publications of the N. A. Rimsky-Korsakov Saint Petersburg State Conservatory. Each issue contained a bibliographical overview of new books ("New literature on folklore, ethnography, ethnolinguistic" by O. V. Trefilova).

Translated by Ekaterina S. Polkovnikova 